\title{
Droplets spectrum of air-assisted boom sprayers under different environmental and operational conditions
}

\author{
Robson S. Sasaki ${ }^{1}$, Mauri M. Teixeira ${ }^{2}$, Haroldo C. Fernandes ${ }^{2}$, \\ Sérgio Zolnier', Christiam F. S. Maciel ${ }^{2} \&$ Cleyton B. de Alvarenga $^{3}$ \\ ${ }^{1}$ Instituto Federal de Minas Gerais/Departamento de Engenharia e Computação. Bambuí, MG. E-mail: robsonufv@gmail.com (Corresponding author) \\ ${ }^{2}$ Universidade Federal de Viçosa/Departamento de Engenharia Agrícola. Viçosa, MG. E-mail: mauri@ufv.br; haroldo@ufv.br; zolnier@ufv.br; \\ christiam.maciel@ufv.br \\ ${ }^{3}$ Universidade Federal de Uberlândia. Monte Carmelo, MG. E-mail: cleyton@iciag.ufu.br
}

\section{Key words:}

evaporation

spraying

pesticides

\begin{abstract}
A B S T R A C T
During pesticide spraying, the psychrometric conditions of the air may cause evaporation of the droplets along their trajectory from the nozzle to the target. Thus, this study aimed to evaluate the effect of air psychrometric conditions and operating pressure on the droplet spectrum of air-assisted boom sprayers. The test was performed using a prototype equipped with an axial fan, a flow homogenizer, temperature and relative air humidity sensors, a spray nozzle and a gas-heating system to warm up the airflow. With the assembled system and the aid of a particle analyser, the JSF 11002 spray nozzle was evaluated with respect to droplet spectrum in four air psychrometric conditions $(7,14,21$ and $28 \mathrm{hPa})$ and at four operating pressures $(200,300,400$ and $500 \mathrm{kPa})$. At the end, evaporation losses were observed during the sprayings. For a given operating pressure and for each increment of $1 \mathrm{hPa}$ in vapor pressure deficit, there was a diameter reduction of approximately 0.0759 , 0.518 and $1.514 \mu \mathrm{m}$ for the parameters $\mathrm{DV}_{0.1}, \mathrm{DV}_{0.5}$ and $\mathrm{DV}_{0.9}$, respectively. The diameter of the droplets decreased as the operating pressure increased.
\end{abstract}

\section{Palavras-chave:}

evaporação

pulverização

agrotóxicos

\section{Espectro de gotas de pulverizadores hidráulicos assistidos a ar sob diferentes condições ambientais e operacionais}

\section{R E S U M O}

Durante a aplicação de agrotóxicos as condições psicrométricas do ar podem acarretar a evaporação das gotas no seu trajeto entre a ponta e o alvo. Neste sentido objetivou-se, com este trabalho, avaliar o efeito das condições psicrométricas do ar e a pressão de trabalho no espectro de gotas da pulverização hidráulica com assistência de ar na barra. O ensaio foi realizado empregando-se um protótipo dotado de um ventilador axial, homogeneizador de fluxo, sensores conjugados de temperatura e umidade relativa, ponta hidráulica e sistema de aquecimento do ar a gás. Com o sistema montado e com o auxílio de um analisador de partículas, avaliou-se a ponta hidráulica JSF 110-02 quanto ao espectro de gotas em quatro diferentes condições psicrométricas do ar $(7,14,21$ e $28 \mathrm{hPa})$ e em quatro pressões de trabalho (200; 300; 400 e $500 \mathrm{kPa})$. Ao final, observaram-se perdas por evaporação durante as pulverizações. Para a pressão de trabalho a cada incremento de $1 \mathrm{hPa}$ no valor do déficit de pressão, ocorreu redução do diâmetro das gotas na ordem de 0,0759; 0,518 e 1,514 $\mu \mathrm{m}$ para os parâmetros de $\mathrm{DV}_{0,1}, \mathrm{DV}_{0,5}$ e $\mathrm{DV}_{0,9}$, respectivamente. O diâmetro das gotas reduziu com a elevação da pressão de trabalho. 


\section{INTRODUCTION}

The correct application of pesticides is a complex activity that involves the characteristics of the pest and/or disease, selection of the product, calibration and regulation of the machines, ability of the operator, besides the meteorological conditions at the moment of the application; taking into consideration all of these parameters, it is possible to perform a good application.

It can be said that the size of the droplets is one of the main parameters for the efficiency of pesticide application. When small droplets are used, the coverage of the target tends to increase, as observed by Wolf et al. (2009) and Lenz et al. (2011). However, the fraction of droplets smaller than $100 \mu \mathrm{m}$ can drift away (Arvidsson et al., 2011) and evaporate under conditions of low relative air humidity. In the case of very large droplets, there is the concern about losses of the liquid as it falls on the leaf and runs down, thus reducing the efficiency of pest control (Lešnik et al., 2005). In the regulation of the sprayer, droplets with enough diameter to allow a good coverage of the target must be selected, suffering little influence of climatic conditions at the moment of the spraying, especially with respect to drift and evaporation.

Although the concept of droplet size is well consolidated, it is known that during pesticide application the meteorological conditions can alter the behavior of the droplet along its trajectory between the hydraulic nozzle and the target. Ranz \& Marshall (1952) proposed a model to describe the evaporation of drops and observed that the rate of reduction in droplet diameter over time is a function of vapor pressure deficit (VPD) and its diameter. The larger the VPD and smaller the droplet diameter, the higher is the rate of reduction in its diameter. Yu et al. (2009) evaluated the effect of relative air humidity on the time of evaporation of droplets and observed that, as humidity increased, the evaporation time also increased. The time necessary for one droplet of $343 \mu \mathrm{m}$ to evaporate, in artificial hydrophilic targets, was 116 and $51 \mathrm{~s}$ for relative humidity conditions of 90 and 30\%, respectively.

The psychrometric conditions of the air can lead to evaporation of the sprayed droplets and, consequently, losses of the product to the environment. There is the need for studies on this area, using air-assisted sprayers. In this context, this study aimed to evaluate the effect of air psychrometric conditions and the operating pressure on droplet spectrum of an air-assisted boom sprayer.

\section{Material ANd Methods}

The tests were performed in the Laboratory of Agrochemical Application Technology, at the Department of Agricultural Engineering of the Federal University of Viçosa.

In order to investigate the effect of air psychrometric conditions in sprayers equipped with fans on spray parameters, a prototype sprayer was developed and consisted of a wind tunnel, a fan, a flow homogenizer and coupled sensors of temperature and relative air humidity (model Humitter 50Y, Vaisala Inc., Woburn, MA, USA) (Figure 1).

The prototype had a total length of $3.5 \mathrm{~m}$, with a metallic pipe installed $1 \mathrm{~m}$ before the fan and a PVC pipe with length of $2.5 \mathrm{~m}$ installed after the fan. The entire structure had a diameter of $0.25 \mathrm{~m}$. An axial fan (Model 10, Rolfes Manufacturing Co., Iowa, EUA) with diameter of $0.25 \mathrm{~m}$ was used, which was operated by a single-phase motor of $110 \mathrm{~V}$ and $5.6 \mathrm{~A}$, with power of $0.19 \mathrm{~kW}$.

Initially, the fan was tested for wind flow and speed, using the method established by the Air Moving and Conditions Association (AMCA), and the respective results were $35.15 \mathrm{~m}^{3} \mathrm{~min}^{-1}$ and $11.94 \mathrm{~m} \mathrm{~s}^{-1}$.

According to the developed prototype and aiming to verify the effect of air temperature on droplet spectrum, a hydraulic nozzle (model JSF 110-02) was installed at the outlet of the wind tunnel. The hydraulic nozzle was operated through a hydraulic piston pump (Yamaho), with rotation of 70-900 rpm and maximum pressure of $3,516 \mathrm{kPa}$. This pump was operated by an electrical motor (WEG), with rotation of 3,570 rpm and power of $1.5 \mathrm{~kW}$. A manometer, properly calibrated using an A3-class standard manometer, was installed close to the hydraulic nozzle. The manometer used showed high accuracy in relation to the standard manometer, with maximum difference of $20 \mathrm{kPa}$ between pressure readings.

With the aid of a real-time particle analyzer (Spraytech, Malvern Instruments Co), equipped with a $750-\mathrm{mm}$ focal lens and set to count droplets from 0.10 to $2,500 \mu \mathrm{m}$ at the acquisition rate of $2.5 \mathrm{kHz}$ and reading time of $1.5 \mathrm{~s}$, droplet spectrum tests were performed, maintaining a distance of $0.5 \mathrm{~m}$ between the laser beam and the hydraulic nozzle. The

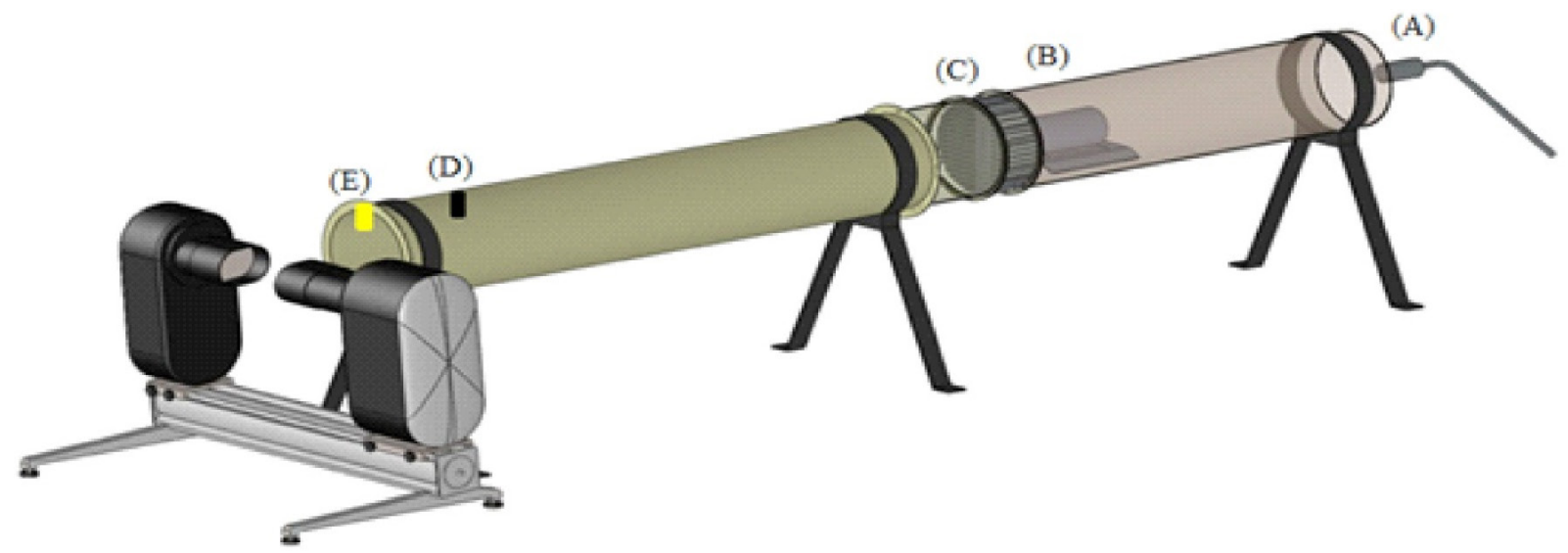

Figure 1. Prototype used in the experiment: Gas heater (A), Fan (B), Air homogenizer (C), Sensors of temperature and relative air humidity $(\mathrm{D})$ and Hydraulic nozzle $(\mathrm{E})$ 
evaluated parameters were: $\mathrm{DV}_{01}$ (Droplet diameter when $10 \%$ of the sprayed liquid volume consists of droplets with size smaller than this value); $\mathrm{DV}_{0.5}$ (Droplet diameter when $50 \%$ of the sprayed liquid volume consists of droplets with size smaller than this value); $\mathrm{DV}_{0.9}$ (Droplet diameter when $90 \%$ of the sprayed liquid volume consists of droplets with size smaller than this value); Span index; $\% \mathrm{~V}<100 ; 100<\% \mathrm{~V}<$ $200 ; 200<\% \mathrm{~V}<300 ; 300<\% \mathrm{~V}<400 ; 400<\% \mathrm{~V}<500 ; 500$ $<\% \mathrm{~V}<600 ; \% \mathrm{~V}>450$ and $\% \mathrm{~V}>600 \mu \mathrm{m}$, at the pressures of 200, 300, 400 and $500 \mathrm{kPa}$.

The air-heating system of the prototype was regulated in order to change the environmental conditions. Air psychrometric conditions were monitored by the sensors, which emitted an electrical signal proportional to the temperature and relative air humidity at that moment. Then, these signals were interpreted by the microcontroller and read by a computer. An algorithm was created to transform the signals of temperature and relative air humidity automatically into VPD, according to the equations proposed by Tetens (1930), described by Vianello \& Alves (2012). In order to minimize errors, the data were only collected two minutes after stabilization of air psychrometric conditions.

When the entire system was assembled, an experiment was conducted using a completely randomized design, in $4 \mathrm{x}$ 4 factorial scheme, with four vapor pressure deficits $(7,14,21$ and $28 \mathrm{hPa}$ ), four operating pressures $(200,300,400$ and 500 $\mathrm{kPa}$ ) and eight replicates.

Mean values of temperature and relative air humidity, in the evaluation of VPD effect on spray parameters during the tests, are shown in Table 1.

The data were subjected to analysis of variance and a followup analysis of the interaction was performed regardless of $\mathrm{F}$ test significance. Then, regression analyses were performed and the models were selected according to the behavior of the obtained data. The significance of equation coefficients $(\beta)$ was evaluated by t-test at $0.01,0.05$ and 0.1 probability levels and coefficient of determination. The data were analysed using the program
Table 1. Mean values of temperature and relative air humidity during the tests for the different vapor pressure deficit (VPD) treatments

\begin{tabular}{ccc}
\hline $\begin{array}{c}\text { VPD } \\
(\mathbf{h P a})\end{array}$ & $\begin{array}{c}\text { Mean air } \\
\text { temperature }\left({ }^{\circ} \mathbf{C}\right)\end{array}$ & $\begin{array}{c}\text { Mean relative } \\
\text { air humidity (\%) }\end{array}$ \\
7 & 22.36 & 67.21 \\
14 & 25.91 & 55.00 \\
21 & 28.10 & 41.08 \\
28 & 31.83 & 39.37 \\
\hline
\end{tabular}

Sisvar v.5.3 and the regression curves were plotted using the program SigmaPlot v.12. The graphs were shown only when the coefficient of determination $\left(\mathrm{R}^{2}\right)$ was higher than 0.60 .

\section{Results AND Discussion}

In the evaluation of droplet spectrum, except for $\% \mathrm{~V}>$ $450 \mu \mathrm{m}$ and $\% \mathrm{~V}>600 \mu \mathrm{m}$, all the other parameters showed interaction between operating pressure and VPD.

According to the interaction between the evaluated factors, for a certain condition of VPD, $\mathrm{DV}_{0.1}$ decreased with the increment in the operating pressure. At the pressure of $200 \mathrm{kPa}$, a value of 93.98 $\mu \mathrm{m}$ was obtained, which decreased to $68.39 \mu \mathrm{m}$ when the pressure increased to $500 \mathrm{kPa}$. This effect of pressure was observed by Bueno et al. (2013), working with fan-type hydraulic nozzles (AD IA 110-02 and AD IA 110-04) and by Cunha (2007) for nozzles of the series API 110-02 and 110-04 and for low-drift nozzles of the series ADI 110-02. Likewise, as VPD increased for a certain operating pressure, there was a reduction in this parameter of approximately $0.08 \mu \mathrm{m}$ per each hPa increase in VPD. Alvarenga et al. (2014), evaluating the effect of VPD on the deposition of liquid in artificial targets and using a hydro-pneumatic sprayer equipped with JA-1 hydraulic nozzles, observed $\mathrm{DV}_{0.1}$ reduction from 89 to $73 \mu \mathrm{m}$ as VPD increased from 7.6 to $17.6 \mathrm{hPa}$, corroborating the results in the present study (Figure 2A).

The adjusted regression equations for the different evaluated parameters, with the respective coefficients of determination, are shown in Table 2.
A.

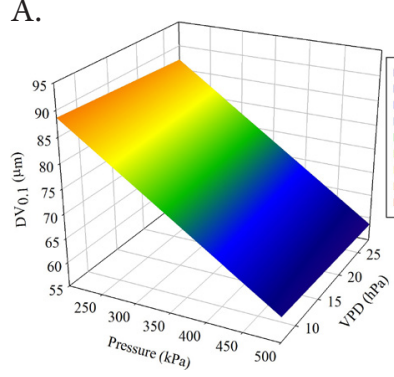

E.

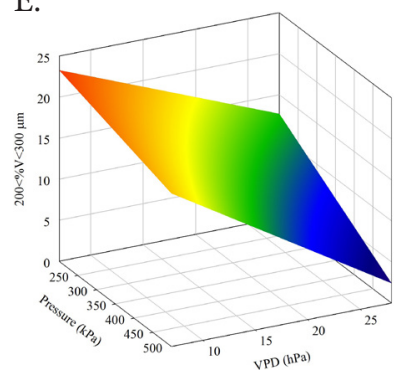

B.
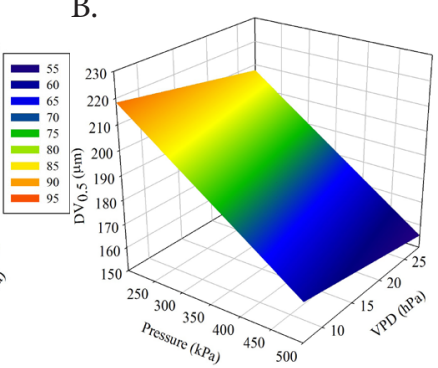

F.
C.

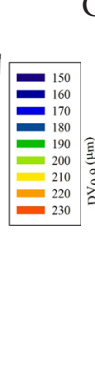

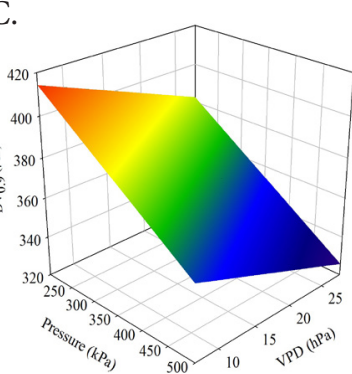

$\mathrm{G}$.
D.
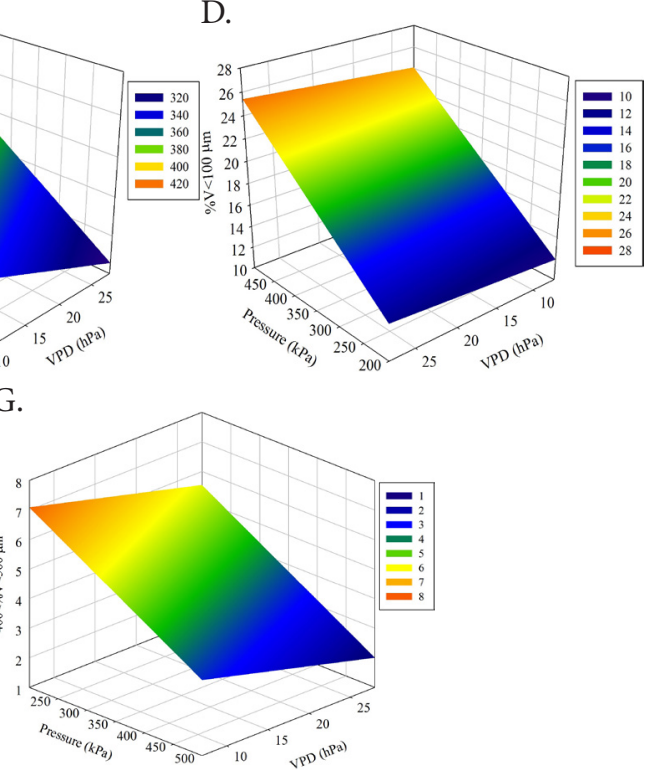

Figure 2. Estimate of spray parameters for the JSF 110-02 nozzle in different conditions of operating pressure and vapor pressure deficit (VPD). $\mathrm{DV}_{0.1}(\mathrm{~A}), \mathrm{DV}_{0.5}$ (B), $\mathrm{DV}_{0.9}(\mathrm{C}), \% \mathrm{~V}<100$ (D), $200<\% \mathrm{~V}<300(\mathrm{E}), 300<\% \mathrm{~V}<400$ (F) and $400<\% \vee<00(\mathrm{G})$ 
Table 2. Adjusted equations for spray parameters as a function of the operating pressure $(\mathrm{P})$ and the vapor pressure deficit (VPD)

\begin{tabular}{|c|c|c|}
\hline Parameter & Adjusted equation & Coefficient of determination $\left(\mathbf{R}^{2}\right)$ \\
\hline $\mathrm{DV}_{0.1}(\mu \mathrm{m})$ & 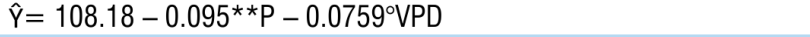 & 0.93 \\
\hline $\mathrm{DV}_{0.5}(\mu \mathrm{m})$ & $\hat{Y}=256.858-0.174^{\star \star} P-0.518^{\star *} V P D$ & 0.95 \\
\hline $\mathrm{DV}_{0.9}(\mu \mathrm{m})$ & $\hat{Y}=462.79-0.189^{\star *} P-1.514^{* \star V P D}$ & 0.82 \\
\hline SPAN (dimensionless) & $\hat{Y}=1.322+0.000932^{* * P}-0.00351 * V P D$ & 0.40 \\
\hline$\% \mathrm{~V}<100(\mu \mathrm{m})$ & $\hat{Y}=3.3926+0.0405^{\star *} P+0.0631^{\star *} V P D$ & 0.92 \\
\hline $100<\% \mathrm{~V}<200(\mu \mathrm{m})$ & $\hat{Y}=26.189+0.0216^{* \star P}+0.147^{* * V P D}$ & 0.56 \\
\hline $200<\% \mathrm{~V}<300(\mu \mathrm{m})$ & $\hat{Y}=28.677-0.00923^{* *} \mathrm{P}+0.3264^{*} \mathrm{VPD}-0.000894^{* *}(\mathrm{P} * \mathrm{VPD})$ & 0.71 \\
\hline $300<\% \mathrm{~V}<400(\mu \mathrm{m})$ & $\hat{Y}=21.583-0.0228^{\star *} P-0.0924^{* * V P D}$ & 0.86 \\
\hline $400<\% \mathrm{~V}<500(\mu \mathrm{m})$ & $\hat{\mathrm{Y}}=9.9694-0.0118^{* *} \mathrm{P}-0.0738^{* *} \mathrm{VPD}$ & 0.68 \\
\hline $500<\% \mathrm{~V}<600(\mu \mathrm{m})$ & $\hat{\mathrm{Y}}=4.971-0.008797^{* *} \mathrm{P}-0.11376^{* *} \mathrm{VPD}+0.0002497^{* *}(\mathrm{P} * \mathrm{VPD})$ & 0.42 \\
\hline
\end{tabular}

${ }^{* *},{ }^{*},{ }^{0}$ Significant at $0.01,0.05$ and 0.10 level of probability, respectively

As observed for the parameter $\mathrm{DV}_{0.1}$, there was a reduction in $\mathrm{DV}_{0.5}$ and $\mathrm{DV}_{0.9}$ with the increase of operating pressure and VPD (Figures 2B and 2C).

Under the evaluated conditions for a given operating pressure, the results show the effect of VPD on spray parameters. There was a reduction in droplet diameter, as the VPD values increased. The reductions in droplet diameter show the effect of evaporation along the trajectory of the droplet from the nozzle to the target. Alvarenga et al. (2014) also observed this relationship using a hydro-pneumatic system. Nascimento et al. (2013) evaluated different application times for the soybean crop and observed that, depending on the hydraulic nozzle used, the density of the droplets deposited on the target can decrease, which shows the effect of droplet evaporation along its trajectory. Yu et al. (2009), under laboratory conditions, with droplets deposited on the target, observed shorter evaporation time with the reduction in relative air humidity, confirming the phenomenon of evaporation with the psychrometric changes in the air, which corroborates the results in the present study. Different results were reported by Maciel (2013), who observed increase in droplet diameter with the increase in VPD; however, unlike the present study, hydraulic fragmentation system without air assistance was used.

By correlating the parameters $\mathrm{DV}_{0.1}, \mathrm{DV}_{0.5}$ and $\mathrm{DV}_{0.9}$, the Span index is obtained, which allows estimating how homogeneous the droplet spectrum is. The adjusted equation shows that, for a given VPD, there was an increase of this index as the pressure increased; for a fixed condition of operating pressure, the index tended to decrease with the increase in VPD (Table 2). This occurs because the spectrum range tends to narrow with the removal of smaller droplets by evaporation, which is similar to the results obtained by Alvarenga et al. (2014).

The Span index has been little mentioned in studies on pesticide application. However, this parameter should not be underestimated, since it provides the notion of droplet size dispersion, i.e., the parameter $\mathrm{DV}_{0.5}$ estimates the size of the droplet used and, along with the Span index, it verifies the degree of homogeneity of the formed droplets; values closer to zero for the Span index indicate a more homogeneous spectrum.

The values obtained for this parameter were considered as satisfactory, since Minguela \& Cunha (2010) recommend values lower than 1.4 for the hydraulic application.

In addition, the effects of VPD were more pronounced at lower pressures, i.e., at the pressure of $200 \mathrm{kPa}$, as the operating pressure increased, the effect of VPD was attenuated.
As to the percentage of the volume that makes up the spectrum, with the increase in the operating pressure, there was a reduction in droplet diameter, thus increasing $\% \mathrm{~V}<100$ $\mu \mathrm{m}$. With the increase in VPD, there was a slight increase in the percentage of volume of this class (Figure 2D). The effect of pressure on the percentage of volume of droplets with diameter smaller than $100 \mu \mathrm{m}$ was also observed by Alvarenga et al. (2012) and Viana et al. (2010).

The percentage of volume of droplets with diameter smaller than $100 \mu \mathrm{m}$ is one of the best parameters to predict the potential risk of drift during the application of pesticides. Arvidsson et al. (2011) and Bueno et al. (2013) also agree with this claim. There is no standard value indicative of risk of drift or safe application; however, values below $15 \%$ of droplets with diameter smaller than $100 \mu \mathrm{m}$ are considered more adequate for environmentally safe applications, with lower risk of drift (Bueno et al., 2013).

The increase in $\% \mathrm{~V}<100 \mu \mathrm{m}$ with the increment in VPD increases the risk of drift. Arvidsson et al. (2011), studying the influences of meteorological conditions on pesticide drift, reported an increase of $0.2 \%$ in the drift of droplets for each degree increase in temperature. Schampheleire et al. (2009), studying strategies for the reduction of drift, observed that high temperatures $\left(26.2^{\circ} \mathrm{C}\right)$ and low relative air humidity $(58.5 \%)$ contributed to higher drift of droplets, compared with other conditions considered ideal, with temperature of $14.7^{\circ} \mathrm{C}$ and relative air humidity of $87.6 \%$.

In the evaluation of the other percentages constituting the droplet spectrum, as the operating pressure increased, at a given air psychrometric condition, the percentage of droplets in the class of diameter until $300 \mu \mathrm{m}$ tended to increase; after this class, the pressure has the opposite effect, i.e., it reduces the percentage of the volume. This also occurred for the effect of VPD (Table 2).

A displacement in droplet size classes was observed with the increase in VPD. As temperatures increase and relative air humidity decreases, the losses through evaporation increase, leading to the reduction in droplet diameter and causing this change of class. Similar results were obtained by Maciel (2013), working with the LD 110-02 nozzle.

In a detailed evaluation of the entire spectrum, it is observed that the air psychrometric conditions at the moment of the application lead to losses through evaporation and immediately change spray parameters.

In a spraying at the field, the negligence with the meteorological conditions of the air at the moment of the 
application is frequent, but it should be pointed out that they can lead to losses through evaporation, thus reducing the control efficiency and resulting in environmental pollution. In order to overcome the obstacles of meteorological conditions, farmers increase the spraying volume. In practice, it may seem like a solution, but in reality, it leads to higher chances of losses to the environment, residues in foods, increase in production costs and reduction of the operation capacity of the machine.

\section{Conclusions}

1. The air psychrometric conditions led to losses through evaporation during the sprayings.

2. For the use of the JSF 110-02 nozzle, at a given operating pressure, there was a reduction in the diameter of droplets with the increment in VPD.

3. For each increment of $1 \mathrm{hPa}$ in VPD, the magnitudes of reduction in droplet diameter were approximately $0.0759,0.518$ and $1.514 \mu \mathrm{m}$ for the parameters $\mathrm{DV}_{0.1}, \mathrm{DV}_{0.5}$ and $\mathrm{DV}_{0.9}$, respectively.

4. There was a reduction in droplet diameter with the increase in the operating pressure.

\section{ACKnowledgments}

To the National Council for Scientific and Technological Development $(\mathrm{CNPq})$ and Foundation for Research Support of the State of Minas Gerais (FAPEMIG) for the financial support.

\section{Literature Cited}

Alvarenga, C. B.; Teixeira, M. M.; Zolnier, S.; Cecon, P. R.; Siqueira, D. L.; Rodriguês, D. E.; Sasaki, R. S.; Rinaldi, P. C. N. Efeito do deficit de pressão de vapor d'água no ar na pulverização hidropneumática em alvos artificiais. Bioscience Journal, v.30, p.182-193, 2014.

Alvarenga, C. B.; Teixeira, M. M.; Zolnier, S.; Sasaki, R. S.; Rinaldi, P. C. N. Efficiency of the spray tip using hydraulic hollow cone from the spectral analysis of the droplets. Brasilian Journal of Applied Technology For Agricultural Science, v.5, p.41-50, 2012.

Arvidsson, T.; Bergstrom, L.; Kreuger, J. Spray drift as influenced by meteorological and technical factors. Pesticide Management Science, v.67, p.586-598, 2011. http://dx.doi.org/10.1002/ps.2114

Bueno, M. R.; Cunha, J. P. A. R.; Roman, R. A. A. Tamanho de gotas de pontas de pulverização em diferentes condições operacionais por meio da técnica de difração do raio laser. Engenharia Agrícola, v.34, p.976-985, 2013. http://dx.doi.org/10.1590/S010069162013000500009
Cunha, J. P. A. R. Análise da distribuição volumétrica de pontas de pulverização hidráulicas de jato plano. Revista de Ciências Agrárias, v.31, p.233-239. 2007.

Lenz, G.; Balardin, R. S.; Minuzzi, S. G.; Tormen, N. R.; Marques, L. N. Espectro de gotas e idade de trifólios na taxa de absorção e efeito residual de fungicidas em soja. Ciência Rural, v.41, p.17021708, 2011. http://dx.doi.org/10.1590/S0103-84782011005000127

Lešnik, M.; Pintar, C.; Lobnik, A.; Kolar, M. Comparison of the effectiveness of standard and drift-reducing nozzles for control of some pests of apple. Crop Protection, v.24, p.93-100, 2005. http:// dx.doi.org/10.1016/j.cropro.2004.06.011

Maciel, C. F. S. Perda de agrotóxicos por evaporação em função das condições psicrométricas do ar. Viçosa: UFV, 2013. 71p. Dissertação Mestrado

Minguela, J. V.; Cunha, J. P. A. R. Manual de aplicação de produtos fitossanitários. Viçosa: Aprenda Fácil, 2010. 588p.

Nascimento, J. M.; Gavassoni. W. L.; Souza, C. M. A.; Bacchi, L. M. A.; Serra, A. P.; Zaccaron, M. L. Pontas de pulverização e horários de aplicação no controle químico de ferrugem asiática da soja. Semina: Ciências Agrárias, v.34, p.2037-2048, 2013. http://dx.doi. org/10.5433/1679-0359.2013v34n5p2037

Ranz, W. E.; Marshall, W. R. Evaporation from drops. Chemical Engineering Progress, v.48, p.141-146, 1952.

Schampheleire, M.; Baetens, K.; Nuyttens, D.; Spanoghe, P. Spray drift measurements to evaluate the Belgian drift mitigation measures in filed crops. Crop Protection, v.27, p.577-589, 2009. http://dx.doi. org/10.1016/j.cropro.2007.08.017

Tetens, O. Uber cinige meteorologische Begriffe. Journal of Geophysics, v.2, p.297-309, 1930.

Viana, R. G.; Ferreira, L. R.; Ferreira, M. C.; Teixeira, M. M.; Rosell, J. R.; Tuffi Santos, L. D.; Machado, A. F. L. Distribuição volumétrica e espectro de gotas de pontas de pulverização de baixa deriva. Planta Daninha, v.28, p.439-446, 2010. http://dx.doi.org/10.1590/ S0100-83582010000200024

Vianello, R. L.; Alves, A. R. Meteorologia básica e aplicações. 2.ed. Viçosa: UFV, 2012. 460p.

Wolf, R. E.; Friedli, C.; Lauer, B. Comparison of spray droplet size and coverage for nozzles used for agronomic weed control. ASABE Meeting Presentation, v.9, p.1-8, 2009.

Yu, Y.; Zhu, H.; Ozkan, H. E.; Derksen, R. C.; Krause, C. R. Evaporation and deposition coverage area of droplets containing insecticides and spray additives on hydrophilic, hydrophobic, and crabapple leaf surfaces. Transactions of the ASAE, v.52, p.39-49, 2009. http:// dx.doi.org/10.13031/2013.25939 